\title{
TRANSNATIONAL FREEDOM OF SPEECH: LEGAL ASPECTS OF THE HELSINKI FINAL ACT
}

\author{
JORDAN J. PAUST* \\ I \\ INTRODUCTION
}

The Final Act of the Conference on Security and Cooperation in Europe was signed in Helsinki, Finland, on August 1, 1975. ${ }^{1}$ However, as explained in a previous article, several international legal documents had already formally acknowledged both the right to freedom of opinion and expression, and the necessarily interrelated right "to seek, receive and impart information and ideas through any media and regardless of frontiers."'2 Thus, by the time the Final Act was signed, a human right to participate in transnational freedom of speech had, in fact, already been widely documented. ${ }^{3}$

The Final Act of the Helsinki conference recognized these developments in human rights law. In principle VII of the Final Act, the participating states reaffirmed their obligation in connection with "human rights and fundamental freedoms" to "act in conformity with the purposes and principles of the Charter of the United Nations and with the Universal Declaration of Human Rights." 4 The Universal Declaration of Human Rights was the document that first expressly rec-

Copyright (C) 1982 by Law and Contemporary Problems

* Professor of Law, University of Houston. A.B. (1965), J.D. (1968), U.C.L.A.; LL.M. (1972), University of Virginia; J.S.D. Cand., Yale University.

1. Conference on Security and Cooperation in Europe: Final Act, Aug. 1975 [hereinafter cited as Final Act, reprinted in 73 Dep'T STATE Bull. 323 (1975), in 14 INT'L L. MATERIALS 1292 (1975), and in 13 VAND. J. TRansnat'L L. 575 (1980).

2. Paust, Intemational Law and Control of the Media: Terror, Repression and the Altematives, 53 IND. L.J. 621 (1978). The article also surveys global trends in governmental repression of many of the human rights noted below. See id. at 631-62 and authorities cited therein.

3. Universal Declaration of Human Rights, G.A. Res. 217A, art. 19, U.N. Doc. A/810, at 71 (1948) [hereinafter cited as Universal Declaration]. On this point, see also Paust, supra note 2, at 625-26, 629-31. With regard to the presently accepted legal nature and utility of the Universal Declaration, see also $M$. McDougal, H. Lasswell \& L. Chen, Human Rights and World Public Order 274, 302, $325-26$ passim (1980); Dimitrijevic,, The Place of Helsinki on the Long Road to Human Rights, 13 VAND. J. TRANSNAT'L L. 253, 268 (1980); Nafziger, The Final Act of the Helsinki Conference: An Artists' Liberation Movement or a Voyage to Laputa?', 26 Clev. ST. L. Rev. 561, 566-67 (1977); Paust, supra note 2, at 625 n.23; Paust, The Unconstitutional Detention of Mexican and Canadian Prisoners by the United Siates Government, 12 VAND. J. TRANSNAT'L L. 67, 70 n.13 (1979); Turack, A Brief Review of the Provisions in Recent Agreements Concerning Freedom of Movement Issues in the Modem World, 11 CASE W. RES. J. INT'L L. 95, 96 (1979) (citing A. ROBERTSON, HuMAN RIGHTS IN THE WORLD $27-28$ (1972)); Paust, Human Rights: From Jurisprudential Inquiry to Effective Litigation (Book Review), 56 N.Y.U. L. REv. 227, 228, 230, 233-41, 244 (1981); see also Cassese, The Approach of the Helsinki Declaration to Human Rights, 13 Vand. J. TransNat'L L. 275, 277 (1980) and infra notes 87, 89.

4. Relevant articles of the Charter include articles 1, 55 and 56. See, e.g., Paust, supra note 2, at 625. It is significant that the UN Charter and the Universal Declaration of Human Rights are cited together, for it 
ognized a transnational freedom of speech which it characterized as the receiving and imparting of information and ideas "regardless of frontiers." 5 Principle VII also declared that the participating states "[would] also fulfill their obligations as set forth in the international declarations and agreements in this field, including inter alia the International Covenants on Human Rights."6

More specifically, principle VII reaffirmed the obligation of the participating states to "respect human rights and fundamental freedoms, including the freedom of thought, conscience, religion or belief, for all without distinction as to race, sex, language or religion." It also confirmed "the right of the individual to know and act upon his rights and duties in this field,"8 and expressly recognized "the universal significance of human rights and fundamental freedoms."9 The Helsinki Final Act contains, as well, an important set of agreements concerning transnational "human contacts" 10 and "the freer and wider dissemination of information." 11 These are found within a section of the Act entitled "Co-operation in Humanitarian and Other Fields," more commonly referred to as "Basket III."

Despite the fact that the Helsinki Final Act stands as an important recognition or reaffirmation of several aspects of human rights law, doubt has been raised concerning its proper use as an international instrument during present and future

is now widely recognized that the Universal Declaration provides, at a minimum, the legally relevant content of the human rights guaranteed to all by the UN Charter. See supra note 3.

5. See supra note 3 .

6. Those covenants include the 1966 Covenant on Civil and Political Rights, approved by G.A. Res. 2200A, 21 U.N. GAOR Supp. (No. 16) at 59, U.N. Doc. A/6316 (1966). The Soviet Union and several East European countries ratified this treaty in 1976, some nine months after the Helsinki Final Act. For evidence of such ratifications, see Multilateral Treaties in Respect of Which the Secretary-General Performs Depository Functions, ST/LEG/SER. D./13, at 111-12 (ratifications of the International Covenant as of 31 Dec. 1979). The United States signed the Covenant on Oct. 5, 1977. See 77 DeP'T State Bull. 578 (1977). Although it has not yet been ratified by the United States, the United States is obligated to take no action that will adversely affect the major purposes of the Covenant: the protection and enjoyment of fundamental human rights. For evidence of such an obligation upon the signing of a treaty, see, e.g., 1969 Vienna Convention on the Law of Treaties, art. 18, at 291, U.N. Doc. A/CONF.39 (1969).

7. As explained above, this obligation and the correlative recognition of the rights of all individuals to a transnational freedom of opinion and expression is widely documented. See supra note 3. Moreover, unlike principle VII of the Final Act, the Universal Declaration of Human Rights also expressly prohibits any distinction on the basis of "colour, . . . political or other opinion, national or social origin, property, birth or other status" as such. Universal Declaration, supra note 3, art. 2.

8. Although the language "know and act upon his rights" is new, it seems merely to follow from an implementation of the documented recognitions and guarantees found, for example, in articles 2 ("[e]veryone is entitled to all the rights and freedoms"), 6 ("right to recognition everywhere as a person"), 7 ("[a]ll are equal before the law and are entitled. . . to equal protection of the law"), and 8 ("right to an effective remedy") of the Universal Declaration. Interrelated, of course, are articles 18 (right to freedom of thought, including the right "alone or in community with others" to "manifest" a "belief in teaching, practice ... and observance"), and 26 (the right to education, including an "education" directed toward "the strengthening of respect for human rights"). Professor Cassese recognizes that the newer Helsinki language is related to rights to "enjoy" human rights and to have "effective domestic remedies" which also relate to corresponding duties of states. See Cassese, supra note 3 , at 286 . On the right to an effective remedy, see also 1966 Covenant on Civil and Political Rights, supra note 6, art. 2, $\mathbb{\Uparrow} 1$ 1, 3.

9. As explained more fully below, this recognition is relevant to the fact that deprivations of fundamental human rights have become matters of international concern and thus are not matters essentially within the domestic jurisdiction of a violator state within the meaning of article 2(7) of the UN Charter. See infra text accompanying notes 103-04.

10. See Final Act, supra note 1, Co-operation in Humanitarian and Other Fields $\$ 1$ [hereinafter cited as Basket III].

11. See id. $\$ 2$. 
efforts to assure a more effective enjoyment by all persons of a transnational freedom of speech. Such doubts are founded on the widespread recognition that the Helsinki conferees did not actually intend to create a legal instrument and, furthermore, that they had expressly declared in principle $\mathrm{X}$ of the Final Act that the Declaration on Principles "[did] not affect their rights and obligations." 12

Yet, a document not initially intended to be legally binding can subsequently take on a legal import or even become part of customary international law. ${ }^{13}$ Has the Helsinki Final Act acquired any such status in the last six years? What is the legal nature of the Final Act? Has it produced any legal effects? What is its present utility? What future potential lies within its words or, more realistically and importantly, within the actual patterns of human subjectivity and practice that condition the legal nature and meaning of any document? These and related questions are explored below.

\section{II}

\section{Legal Nature of the Final Act}

In terms of traditional approaches to the concept of law and a legally binding international instrument, the point has been made several times that the Helsinki Final Act is not a "legal" instrument and is not technically "binding" as such. This view is generally shared by textwriters ${ }^{14}$ and government experts ${ }^{15}$ from the

12. See generally infra notes 14-19. With regard to the import of principle X, see Bastid, The Special Significance of the Helsinki Final Act, in Human Rights, INTERNATIONAL LAW AND THE HELSINki ACCORD 13 (T. Buergenthal ed. 1977); Frowein, The Interrelationship Between the Helsinki Final Act, the Intemational Covenants on Human Rights, and the European Convention on Human Rights, in Human Rights, INTER NaTIONAL LAW AND THE HELSINKI ACCORD 81 n.4 (T. Buergenthal ed. 1977); see also Jonathan \& Jacqué, Obligations Assumed by the Helsinki Signatories, in HuMAN Rights, INTER NATIONAL LAW AND THE Helsinki ACCORD 51 (T. Buergenthal ed. 1977); Kiss \& Dominick, The Intemational Legal Significance of the Human Rights Provisions of the Helsinki Final Act, 13 VAND. J. TRANSNAT'L L. 293, 297 (1980).

13. See, e.g., Buergenthal, International Human Rights Law and the Helsinki Final Act: Conclusions, in Human Rights, InTERnational Law and ThE Helsinki ACcord 6-7 (T. Buergenthal ed. 1977) (setting forth the conclusions of a private conference of U.S. and West European lawyers held in June 1977); Frowein, supra note 12, at 72; Jonathan \& Jacqué, supra note 12, at 53; Schachter, The Twilight Existence of Nonbinding Intemational Agreements, 71 AM. J. INT'L L. 296, 300-01, 304 (1977); see also Kiss \& Dominick, supra note 12 , at 315 .

14. See, e.g., Buergenthal, supra note 13, at 6; Henkin, Human Rights and "Domestic Jurisdiction," in Human Rights, International Law and the Helsinki ACCORd 25 (T. Buergenthal ed. 1977); Kiss \& Dominick, supra note 12, at 296-300, 303, 306, 315; Leary, The Implementation of the Human Rights Provisions of the Helsinki Final Act, A Preliminary Assessment: 1975-1977, in Human Rights, INTER NaTIONAL LAW AND THE Helsinki ACCORD 111 (T. Buergenthal ed. 1977); Schachter, supra note 13, at 296. Cf. L. HENKIN, R. Pugh, O. Schachter \& H. Smitr, International Law 213 (1980); Bishop, Introduction, Symposium: Human Rights and the Helsinki Accord-A Five-Year Road to Madrid, 13 VAND. J. Transnat'L L. 249, 250 (1980); Coughlin, Moniloring of the Helsinki Accords: Belgrade 1977, 10 CASE W. RES. J. INT'L L. 51 1, 512-13, 515 (1978); Fryer, Soviet Human Rights: Law and Politics in Perspective, 43 LAw \& ConTEMP. ProBs. 296, 296 n.4 (1970); Goldberg, Human Rights and the Belgrade Meeting, 30 HASTings L.J. 249, 249 (1978); Kiss \& Dominick, supra note 12, at 307-08, 313,315; Nafziger, supra note 3, at 561, 568; Turack, Freedom of Transnational Movement: The Helsinki Accord and Beyond, 11 VAnD. J. Transnat'L L. 585, 586 (1978); Comment, The Conference on Security and Cooperation in Europe: Implications for Soviet-American Detente, 6 DEN. J. INT'L L. \& POL. 122, 138, 142-44 (1976).

15. See, e.g., Russell, The Helsinki Declaration: Brobdingnag or Lilliput.', 70 AM. J. INT'L L. 242, 246-48 (1976); Russell, Follow-up at Madrid: Another Chance for the United States, 13 VAND. J. TransNaT'L L. 359, 361 (1980); Scholleart, 71 Proc. AM. Soc. INT'L L. 241, 242 (1977); Vest, Remarks by the Assistant Secretary of State, 1978 ABA Law Professor Workshop, reprinted in ABA, Confrontation IN THE AMERICANSOVIET Relationship: CAN IT BE MANAGED? 33 (1980) [hereinafter cited as ABA Workshop]; Nimetz, 


\section{United States, Western Europe, ${ }^{16}$ and Eastern Europe. ${ }^{17}$}

The following statement of European scholars made in a committee report on the Helsinki Final Act for the International Law Association (I.L.A.) is representative: "The Helsinki Final Act, in its dispositions on human rights, does not intend to create new legal obligations. Mutual agreement existed during the whole negotiations that the result of the Conference should . . . be a common declaration but not a legal instrument."18 The I.L.A. committee also recognized that two reports presented at an international symposium in 1976 " [could] be cited in support of this interpretation. Professor Skubiszewski from Poland underlined that the guiding principles of the Act of 1975 were not legally binding rules, but rather a program for future cooperation. . . Professor Delbruck from the Federal Republic of Germany agreed that no legal obligations were intended." 19

Nevertheless, the committee warned, "[t]he participating states, by adhering to these principles, lay down a guide for their future conduct and enter into a moral obligation to conform to these principles."'20 Others have also stressed the view that important moral obligations are inherent in the Helsinki Final Act. ${ }^{21}$ At least one American writer has insightfully added the related point:

Remarks, ABA Workshop at 36, 95; Nimetz, Conference on Security and Cooperation in Europe: Retrospect and Prospect, 13 Vand. J. Transnat'L L. 323, 325 (1980); Oliver, Remarks, ABA Workshop at 35. For similar documented views of the U.S. Government, see Kiss \& Dominick, supra note 12, at 296 n.8, 299 , 306 n.61.

16. See, e.g. , Bastid, supra note 12, at 13; Frowein, supra note 12, at 72; Higgins, Appendix to RePORT OF the United Kingdom Helsinki Review Group, From Helsinki to Belgrade 1 (1977) (Lord 'Thomson, chairman); Jonathan \& Jacqué, supra note 12, at 52; Robertson, The Helsinki Agreement and Human Rights, 53 Notre Dame Law. 34, $34-35$ (1977); Scheuner, Driessen, Lester, Meessen, Menendez, \& Schweissfurth, in RePORT of THE Firty-EIGHTh Conference, Manila, 1978 130-31 (I.L.A. 1980) (authors are members of a committee of the International Law Association which issued the First Preliminary Report of the Sub-committee on the Helsinki Declaration and the Equal Application of Human Rights) [hereinafter cited as ILA REPORT]; Remarks of Delbuck, ILA REPORT, at 130-31 (citing I

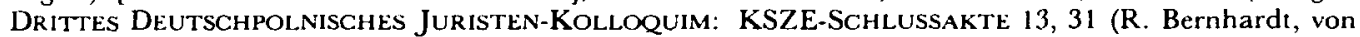
Munch \& W. Rudolf eds. 1977)); Uibopuu, The Intemational Legal Status of Soviet Minorities Today, 2 REV. Socialist L. 217, 218-19 (Leiden 1976); see also Cassese, The Helsinki Declaration and Self-Determination, in Human Rights, International Law and THE Helsinki ACCORd 107 (T. Buergenthal ed. 1977); Schweissfurth, Zur Frage der Rechtsnatur, Verbindlichkeil und völkerrechtlichen Relevanz der KSZE-Schlussakte, 36 ZEITSCHRIFT FUR AUSLÄNDISCHES ÖFFENTLICHES RECHT UND VöLKERRECHT 681 passim (1976), cited in Frowein, supra note 12, at $81 \mathrm{n} .5$ for a similar proposition. For similar documented view's of the French government, see Kiss \& Dominick, supra note 12, at 296 n.8, 297 n.16, 306 n.61. Kiss and Dominick also cite the French author Prevost for a similar proposition. See id. at $296 \mathrm{n} .8$ (citing Prevost, Observations sur la nature juridique de l'Acte final de la Conference sur la Securité el la Coopération en Europe, ANNUAIRE FRANÇAIS DE DROIT INTER NATIONAL 130, 141 (1977)).

17. See, e.g., Dimitrijevic, supra note 3, at 272; Chalidze, The Humanitarian Provisions of the Helsinki Accord: A Critique of Their Significance, 13 VAND. J. TRANSNaT'L L. 429, 434-35 (1980); Pechota, East European Perceptions of the Helsinki Final Act and the Role of Citizen Initiatives, 13 VAND. J. TRANSNAT'L L. 467, 473. Cf. id. at 493; Sherer, Remarks by the Ambassador, 1978 ABA Law Professor Workshop, reprinted in ABA Workshop, supra note 15, at 66; Remarks by Skubiszewski, ciled in ILA REPORT, supra note 16, at 130, 131 n.21; Milojevic, in ILA REPORT, supra note 16, at 130-31, 134 (author is member of ILA Committee).

18. ILA REPORT, supra note 16 , at 130 .

19. Id. at $130-31$.

20. Id. at 130; see also id. at 131 ("It]he Final Act imposes upon them a moral obligation").

21. See, e.g., Buergenthal, supra note 13, at 6 (setting forth a relevant conclusion of a private conference); Cassese, supra note 16, at 107; Dimitrijevic, supra note 3, at 272; Fascell, The CSCE Follow-up Mechanism From Belgrade to Madrid, 13 VAND. J. TRANSNAT'L L. 335, 336 (1980); Jonathan \& Jacqué, supra note 12, at 52-53; Kiss \& Dominick, supra note 12, at 300; Nafziger, supra note 3, at 561; Robertson, supra note 16, at 35; Russell, The Helsinki Declaration, supra note 15, at 248 ("deemed to be a moral commitment"); Schachter, supra note 13, at 304; Turack, supra note 14, at 586; Remarks by Assistant Secretary of State 
As long as they do last, even nonbinding agreements can be authoritative and controlling for the parties. There is no a priori reason to assume that the undertakings are illusory because they are not legal. . . . It would seem wiser to recognize that nonbinding agreements may be attainable when binding treaties are not and to seek to reinforce their moral and political commitments when they serve ends we value. ${ }^{22}$

Professor Vojin Dimitrijević from Yugoslavia might add:

It is to be expected that the signatory States would not risk political and moral responsibility (which for states as well as individuals can sometimes be more painful than legal sanctions) by not complying with the agreed obligations. This . . . is not only experienced in the form of criticism. . . . Constant reminders by the public abroad and at home threaten a nation's prestige, which is in itself an element of power to be neglected only at one's own peril. 23

The main point, which is shared by the last two writers, is profound. It not only raises questions concerning a functional difference between legal obligations and moral-political obligations, but also points toward the kind of inquiry one might make in order to address more realistically the problems and potential approaches to solution involved in any effort to implement an international agreement.

Other views have been expressed; some even suggest that the act represents actual legal obligations. For example, a Czechoslovak writer has stated that the Final Act, like the 1966 Covenants, sets forth "binding standards that ought to be followed," 24 even though "[ $\mathrm{t}]$ he official position of most East European countries is that the Helsinki Accord confers no rights directly on the individual."25 He gives much of his argument away, however, when he asks: "Why not . . . take a bolder step by giving the Final Act tacit or implicit recognition as a legally binding obligation?"26 Implicitly, the writer acknowledges that such a recognition does not now generally exist.

Professor Christopher Osakwe points out that certain Soviet authors "contend, most unequivocally, that the Helsinki Accord is a binding document" and a "source of international law." 27 Some even declared that the Final Act "has a special political and legal significance, . . . contains independent normative rules

Vest, ABA Workshop, supra note 15, at 33; see also Nimetz, ABA Workshop, supra note 15, at 96 ("reflects basic Western values. . our own values").

22. Schachter, supra note 13, at 304. For a related view that "moral and political obligations are not necessarily illusory," see Jonathan \& Jacqué, supra note 12, at 53 (citing Virally, La Décennie pour le développement, Annuaire Françals de Drott International, at 29 (1970)); Schreuer, Recommendations and the Traditional Sources of Intemational Law, 20 GERMAN YRBK. INT'L. L. 103, 104-05, 112-18 (1977).

23. Dimitrijević, supra note 3 , at $272-73$. On this point, see also Jonathan \& Jacqué, supra note 12 , at 53, adding: "For the defaulting state, the failure to fulfill moral and political obligations would entail a loss of prestige and credibility. . . "; Kiss \& Dominick, supra note 12, at 300 (costs and benefits). The Staff Director and General Counsel to the U.S. Commission on Security and Cooperation in Europe has also stated: "Brezhnev and the Soviet leadership have attached their own personal political prestige to the Final Act. It is very difficult for the Soviets to renounce the Helsinki Final Act or to ignore it." Oliver, supra note 15, at 35. On Brezhnev's personal stake, see also Russell, The Helsinki Declaration, supra note 15, at 246.

24. Pechota, supra note 17, at 468. Pechota equates the Final Act with the 1966 Covenants and the Universal Declaration of Human Rights.

25. Id. at 473 ; see also id. at 480 (official hostility), 482 passim.

26. Id. at 494 .

27. Osakwe, Contemporary Souiet Doctrine on the Sources of General Intemational Law, 73 Proc. AM. SoC. INT'L L. 310, 322 (1979). For further evidence of a Soviet view that international practice shows that states are bound by the Helsinki Final Act, see Uibopuu, supra note 16, at $229 \mathrm{n} .14$ (citing the Soviet author $\mathrm{S}$. Malinin, Soveshchanie v. Helsinki (1975 g.) i mezhdunarodnoe pravo, Pravovedenie 1976, No. 2, 22). 
.. . [and was] officially recognized by all participating states as constituting a component part of the international law in force." 28 Nevertheless, others suggest that the Soviets generally were not interested in recognizing new human rights obligations and that any Soviet reference to binding obligations is best related to the Helsinki provisions on the use of force and impermissible intervention. ${ }^{29}$

The Soviet authors quoted above were referring to the legal nature of the Final Act in its totality. ${ }^{30}$ They were necessarily, therefore, referring to the human rights provisions of the act as well. Moreover, the acknowledged Soviet tendency "to distinguish between the legally binding nature of the Declaration of Principles and the recommendatory or programmatic character of other provisions," such as the Basket III provisions, ${ }^{31}$ does not preclude the inference that the Soviets recognize that the Helsinki Act contains legal obligations pertaining to human rights. This is especially true because principle VII of the Declaration on Principles is expressly directed toward recognition and implementation of the human rights of all persons. ${ }^{32}$ Nevertheless, it would seem partly unrealistic to assume that such a recognition, even if widely shared among Soviet elites, would allow one comfortably to conclude that the Soviets feel legally bound to implement the normative phrases " contained in principle VII. Not only is the Soviet view regarding implementation of human rights quite different, at least overtly, from that of much of the international community, ${ }^{33}$ but there is also little evidence to suggest that the existing official governmental view is different from actual Soviet practice either prior or subsequent to the formal signing of a document at Helsinki. That practice, in fact, has been thwarting of the human rights mentioned in the Final Act. ${ }^{34}$

28. Osakwe, supra note 27 , at 322 (quoting G. Ignatenko \& D. Ostapenko, International. LaW $71.72(1978))$.

29. See, e.g., Jonathan \& Jacqué, supra note 12, at 43; Russell, The Helsinki Declaration, supra note 15, at 244-46; Comment, supra note 14, at 125, 135-36, 143; see also Dean, Beyond Helsinki. The Soviet View of Human Rights in Intemational Law, 21 VA. J. INT'L L. 55, 84-85 (1980); Robertson, supra note 16, at 38; infra text accompanying note 31 .

30. See G. IGNATENKo \& D. Ostapenko, supra note 28 ; $c$. infra text accompanying note 31.

31. Pechota, supra note 17 , at 493.

32. See supra text accompanying notes 4-9. At least one U.S. official has written that the human rights provisions in the Declaration on Principles are more important than those contained in "the well-publicized Basket III" portions of the Final Act. Nimetz, supra note 15, at 325. A European writer agrees. See Robertson, supra note 16 , at 36 .

33. See, e.g., Uibopuu, The Human Rights Covenants of the United Nations and the Constitutional Law of the USSR, in PAPERS ON SOVIET LAW 14 (1977); Uibopuu, The Intemational Legal Obligations of the USSR for the Protection of Individuals, 14 Co-EXISTENCE 266 (1977); Dean, supra note 29, and authorities cited therein; Feldbrugge, The Soviet Human Rights Doctrine in the Crossfire Between Dissidents at Home and Critics Abroad, 13 Vand. J. TRansnat'L L. 451 (1980); Paust, supra note 2, at 646-50, and authorities cited therein; see also M. MCDougal, H. Lasswell \& L. CHEN, supra note 3, at 76-79; Funk, Lessons of Soviel Jurisprudence: Law for Social Change Versus Individual Rights, 7 IND. L. REv. 449 (1974). On Soviet violations of human rights law, see Chalidze, supra note 17, at 431-34, 447-48; Fryer, supra note 14; Goldberg, Human Rights and the Belgrade Meting, 13 Vand. J. TRanSNat'L L. 319-20 (1980); Goldberg, supra note 14, at 251-52; Grzybowski, Penal Regimes and Dissenters in the Soviel Orbil, 43 Law \& ConTeMP. Probs. 289 (1979); Human Rights Comm'n, World Congress of Free Ukrainians, The Persecution of the Ukrainian Heisinki Group (Canada 1980); Leary, supra note 14, at 122-26 passim; Leary, The Right of the Individual to Know and Act Upon His Rights and Duties: Moniloring Groups and the Helsinki Final Acl, 13 Vand. J. TransNat'L. L. 375 (1980); Nafziger, supra note 3, at 565-56; Turack, supra note 2, at 112-13; Turack, supra note 14, at 591, 60607.

34. See, e.g., supra note 33. For more recent evidence, see also Killing the Spirit of Helsinki: $A$ lough new crackdown on dissidents, Time, Dec. 1, 1980, at 45; Marchenko, a Dissident, Goes on Trial in Soviet, N.Y. Times, 
This realization might be painful for those keenly interested in alleviating the human suffering and injustice that is necessarily involved in the deprivation of fundarnental human rights. Nevertheless, not every conference document that mentions human rights is actually authoritative in the community. Nor is every such document reflective of general patterns of legal expectation and behavior or of ongoing social patterns that form the basis of law in any particular or more general social process. ${ }^{35}$ Certainly a "nonbinding" document may reflect one or more legal norms that are recognized in customary law, some authoritative legal instrument, or both. ${ }^{36}$ The Final Act contains at least some presently recognized legal norms. Moreover, a "nonbinding" document can contribute through time to the shaping of attitudes and behavior to such an extent that it becomes accepted either as a legally relevant aid for the interpretation of other international ${ }^{37}$ and domestic ${ }^{38}$ legal instruments, or as evidence of customary international law. ${ }^{39}$

Sept. 3, 1981, at 5, col. 4; Musical Freedom and Why Dictators Fear It, N.Y. Times, Aug. 23, 1981, § 2, at 1, col. 5; N.Y. Times, Aug. 15, 1981, at 4, col. 6 (five-year term of internment for defaming the state in an underground journal); Demonstration Seeks to Aid Dissident, Hous. Chronicle, Aug. 6, 1981, at 17, col. 1 (U.S.-born Lithuanian serving a seven and one half year sentence for writing anti-Soviet article); N.Y. Times, Aug. 3, 1981, at 14, col. 6 (letter to the editor); Moscow Silencing Psychiatry Critics, N.Y. Times, July 26, 1981, at 3, col. 1; Soviet Lifts Citizenship of a Satirical Writer, N.Y. Times, July 18, 1981, at 5, col. 6; Soviet Psychialrist Held, Hous. Chronicle, Feb. 19, 1981, at 8, col. 6 (psychiatrist and engineer); U.S. Repart Says Status of Rights Improved During '80, N.Y. Times, Feb. 10, 1981, at 10, col. 1; Soviel Is Said to Give Jail Terms to 2 Dissidents From Lithuania, N.Y. Times, Sept. 21, 1980, at 15, col. 5; Dissident Russian Priest Is Given 5-Year Sentence, N.Y. Times, Aug. 29, 1980, at 9, col. 3; Carter Assails Soviets on Rights, L.A. Times, July 30, 1980, at 5, col. 3; Soviet Police Said to Accuse Activist of an Olympics Plot, N.Y. Times, July 10, 1980, at 7, col. 1; Rights Group Says Soviet Has Detained 400 Dissidents, N.Y. Times, Apr. 30, 1980, at 6, col. 2.

35. See, eg., M. MCDougal, H. Lasswell \& L. Chen, supra note 3, at 273; see also Schreuer, supra note 22. On the more general jurisprudential point, see, e.g., M. MCDOUGAL, H. LASSWELL \& L. CHEN, supra note 3; Paust, The Concept of Norm: Toward a Betler Understanding of Content, Authority, and Choice, 53 TEMP. L.Q. 226 (1980). As Professor Michael Reisman has recently remarked, conference documents that are not expected to reflect law, although they contain certain terms that read like legal terms, are not law. He also stressed the difference between what he termed lex simulata or "pretend law" and law actually extant in the social process. See Reisman, International Laumaking: A Process of Communication, 75 PROC. AM. SOC. INT'L L. (1981) (in press).

36. See, e.g., M. MCDOUGal, H. LAsswell \& L. CHEN, supra note 3, at 274; Buergenthal, supra note 13, at 6, 8; Jonathan \& Jacqué, supra note 12, at 45-46, 52; see also Kiss \& Dominick, supra note 12, at 315; Schreuer, supra note 22, at 106-10. It is perhaps for this reason that Rosalyn Higgins has suggested that a great part of the Final Act is binding. See Higgins, supra note 16, at 1 ("not . . . without legal significance" and confirms "already binding" human rights law), 4, 7-11.

37. See, e.g., M. McDougal, H. LAsswell \& L. Chen, supra note 3, at 274, 302, 325-26, 330; Buergenthal, supra note 13, at 6-7; Frowein, supra note 12, at 72; Schwelb, The Inftuence of the Universal Declaration of Human Rights on International and National Law, 53 Proc. AM. SOC. INT'L L. 217, $219-22$ (1959). For a recent U.S. case utilizing the Universal Declaration of Human Rights in this and similar ways, see Filartiga v. Pena-Irala, 630 F.2d 876, 882-83 (2d Cir. 1980).

38. See, e.g., M. MCDOugal, H. LASswell \& L. Chen, supra note 3, at 330; Schreuer, supra note 22, at 104; Schwelb, supra note 37, at 222-27; United Nations Action in the Field of Human Rights, ST/HR/2, at 17-18, U.N. Sales No. E.74.XIV.2 (1974). For a recent U.S. case, see Filartiga v. Pena-Irala, 630 F.2d 876 (2d Cir. 1980) (interpreting a U.S. statute). On this general point, see also Paust, supra note 2, at 66669; Paust, Human Rights, supra note 3, at 230-31, 233 n.26, 235-37, 240-42, 244, and cases cited therein.

39. See, e.g., M. MCDougal, H. LAsswell \& L. CHEN, supro note 3, at 274, 325-26; Buergenthal, supra note 13, at 6; see also Cassese, supra note 16, at 107; Kiss \& Dominick, supra note 12, at 315 ; Russell, The Helsinki Declaration, supra note 15, at 248 (many think the Helsinki Final Act may become a source of customary law); Schachter, supra note 13, at 300 . For recent U.S. cases using the Universal Declaration of Human Rights as evidence of customary law, see Filartiga v. Pena-Irala, 630 F.2d 876 (2d Cir. 1980); Fernandez v. Wilkinson, 505 F. Supp. 787, 795-98 (D. Kan. 1980), aff' on other grounds, 654 F.2d 1382, 1388 (10th Cir. 1981) (still using the Universal Declaration as an interpretive aid); Lareau v. Manson, 507 F. Supp. 1177, 1193 n.18 (D. Conn. 1980). These are reviewed in Paust, Human Rights, supra note 3, at 230-37, 
Unfortunately, the Helsinki Final Act has not yet achieved such an acceptance, even though it has already produced domestic legal effects.

In view of the above, one can sympathize with a recent effort by Professor Alexandre Kiss and Mary Dominick to reconstitute the Final Act as "one of the new forms of international legal instruments," 40 "a special category of international legal instruments . . . [:] non-binding, but directive texts which produce limited legal effects" 4 and which have "a specific legal nature as an internationally agreed upon program." 42 But law and legal natures cannot simply be wished into existence when the relevant social community does not consider such a document a legal one or, more importantly, when it is not the case that each of its provisions reflects patterns of generally shared legal expectation. Kiss and Dominick admit that "the general consensus [during formation] was to deny binding character to its provisions," 43 and that subsequent practice of the participating states has "constantly stressed the non-binding character of the Final Act." 44 Further, most writers agree that the act "creates mainly moral and political obligations," 45 that it presently has "no binding [legal] character," 46 and that whether or not it "will lead to the creation of customary international law is an open question." 47 Thus, the needed base of generally shared legal expectation concerning the act as such is presently lacking.

What Kiss and Dominick seem to substitute for the missing patterns of expectation, or opinio juris, is the admitted fact that the Final Act has produced "legal effects." 48 They argue that these effects "place it within the scope of international law."49 The circle of reasoning does not close, however. It simply does not follow that because a document produces "legal effects" (for example, a change in a domestic statute), it is itself a legal document, a legally binding document, "a special category of international legal instruments,"50 or even a document that has "a specific legal nature."5t Such a status is for the future.

Similarly, Professor William Bishop has recognized that the Final Act "is not legally binding," and adds, "[n]onetheless, in some respects it has been talked about and treated almost as if it were a legal commitment by the states which are parties." 52 If such talk and treatment continue, and someday help to shape pat-

240-44. This general method of normative development has long been recognized by the United States Supreme Court. See, e.g., The Paquete Habana, 175 U.S. 677, 700 passim (1900); Filartiga v. Pena-Irala, 630 F.2d at 880-84; Paust, Comment, 18 VA. J. INT'L L. 601 (1978); Paust, supra note 2, at 666-70, and cases cited therein.

40. Kiss \& Dominick, supra note 12 , at 308 .

41. Id. at 314-15.

42. Id. at 313 .

43. Id. at 296 .

44. Id. at 296 n.8.

45. Id. at 300 .

46. Id. at 303, 307; see also id. at 296-300, 312-13, 315.

47. Id. at 315 .

48. See id. at $300,303,312,315$.

49. Id. at 307 ; see also id. at 314-15.

50. See supra note 41.

51. See supra note 42.

52. Bishop, supra note 14 , at 250 . 
terns of more widespread and intensely held legal expectation, a document not now legally binding as such may become a "legal instrument."53 Knowing this, some writers may even have intentionally utilized words such as "duty,"54 "rules," 55 or "violations" 56 (without the qualifiers "moral" or "political") in an attempt to further such an outcome.

It is also noteworthy that some private Helsinki monitoring groups may actually believe that the Final Act is a legal instrument and may be seeking to promote such an expectation. On the other hand, they may simply share the more common opinion that the Final Act is an important political document that recognizes, in significant ways, that a human rights law exists and must be effectively guaranteed and implemented according to the UN Charter and the Universal Declaration of Human Rights. ${ }^{57}$ In any event, the private monitoring groups themselves are an important outcome and part of the ongoing Helsinki process. As explained below, they also contribute significantly to the many legal effects which flow from such a process.

\section{III}

\section{Legal Effects of The Helsinki Process}

\section{A. Private Monitoring Groups}

Several writers have commented on the fact that the Helsinki Final Act was one of the main catalysts for the creation of private human rights monitoring groups. ${ }^{58}$ The creation of these private groups and their role as defenders of human rights has been termed "a development which few at Helsinki in 1975 could have predicted." 59 Yet it is this development which may well have placed the humanitarian provisions of the Helsinki Final Act in recorded history. For example, Valery Chalidze states that such a historic place has been reserved for these provisions "by virtue of not so much their content as the strong public response they have elicited."60

53. See, e.g., supra notes 37,39 .

54. See, e.g., Cassese, supra note 2, at 286; see also Goldberg, supra note 33, at 320 ("obligations").

55. See, e.g., Pechota, supra note 17, at 492; see also id. at 468 ("binding standards").

56. See, e.g., Goldberg, supra note 33, at 320; see also Pechota, supra note 17, at 472 ("infringements of the obligations assumed").

57. On the more recently accepted nature of human rights law, nation-state obligations, and individual rights (including the right to an effective remedy identifiable in article 8 of the Universal Declaration of Human Rights, as supplemented by articles 1, 2, 6 and 7 of the Declaration), see generally supra notes 2-8 and the symposium on litigating human rights, 4 Hous. J. INT'L L. 1 (1981).

58. See, e.g., Cabranes, Reflections on the Belgrade Meeting (1977-78) of the Conference on Security and Cooperaiion in Europe, 4 YALE STUD. WORLD PUB. ORDER 274, 277, 279 (1978); Chalidze, supra note 17, at 430-31; Errera, Charter 77 in Czechoslovakia and the International Protection of Human Rights, 13 VAND. J. TRANSNAT'L L. 409-10 (1980); Leary, supra note 33, at 375-76; Leary, supra note 14, at 121-25; Pechota, supra note 17, at 479; Robertson, supra note 16, at 38-40; Oliver, ABA Workshop, supra note 15, at 36-38; Human Rights Comm'n, World Congress of Free Ukrainians, supra note 33, at 5 . The other main catalyst was the ratification by many states of the UN Covenants. See, e.g. , Errera, supra at 409-10, 412, 425-26, 428; Robertson, supra note 16 , at 38 .

59. Errera, supra note 58, at 428; see also Leary, supra note 33 , at 375 ; Robertson, supra note 16 , at 40 ; Oliver, ABA Workshop, supra note 15, at 36-37.

60. Chalidze, supra note 17, at 429, adding: "The Helsinki Accord created more world public interest than much more complete documents of international law guaranteeing human rights." Id. at 429-30 n.1. 
Although many of the East European members of such groups have suffered greatly as a result of governmental crackdowns, ${ }^{61}$ their suffering has attracted greater attention to human rights law and to the need for more adequate implementation of the human rights of all persons. The efforts of such groups have increased the general awareness of governmental violations of human rights. ${ }^{62}$ They have also contributed to several "linkages" between and among individuals and groups ${ }^{63}$ which are likely to add an important dimension to ongoing efforts at private implementation and sanctioning of international law. ${ }^{64}$ In this sense, these groups are on the "front line" of such an effort, stimulated in part by the Helsinki process.

There are, of course, many Helsinki monitoring groups in the West whose activities also contribute to the "legal effects" of the Final Act. ${ }^{65}$ There are even groups monitoring the performance of the U.S. Government. ${ }^{66}$ As suggested by Professor Virginia Leary, these private implementary groups are not only the product of the Helsinki Final Act, but also are legitimized by the portion of principle VII of the act wherein the participating states "confirm the right of the individual to know and act upon his rights and duties." 67 Nevertheless, such a right arguably had already existed in more authoritative human rights instruments ${ }^{68}$ and was merely supplemented in an important way or "confirmed" by the Helsinki Final Act. In any event, the Helsinki process has certainly furthered transnational efforts to make each human being's right "to seek, receive and impart information and ideas . . . regardless of frontiers" more meaningful. 69

See also Leary, supra note 33, at 394 ("one of the most important contributions" of the Final Act has been the spawning of private monitoring groups).

61. See, e.g., supra notes 33-34; Chalidze, supra note 17, at 431, 434; Coughlin, supra note 14, at 517; Errera, supro note 58, at 410-11, 421-25; Leary, supra note 14, at 122-25; Leary, supra note 33 , at $377-83$, 387; Paust, supra note 2, at 646-52; Pechota, supra note 17, at 480-84, 486, 488-89; Turner, The Artist in the Amphitheatre, 43 LAW \& CONTEMP. PrOBS. 308, 308-10, 312, 318 (1979); Turack, supra note 2, at 112-13; Turack, supra note 14, at 591-92, 597-98, 606-07; 15 Czechoslovak Dissidents Reported Seized in Prague, N.Y. Times, June 3, 1980, at 5, col. 2; Visiting British Educator Expelled by Czechoslovaks, N.Y. Times, Apr. 15, 1980, at 5, col. 2; Czechs Said to Release Dissident Jailed 3 Years, N.Y. Times, Jan. 14, 1980, at 7, col. 6.

62. See, e.g. , supra note 61; Statement of President Carter, quoted in ABA Workshop, supra note 15, at 35 n.23, 114; Oliver, supra note 15 , at $37-38,78,119$.

63. See Oliver, supra note 15, at 38; see also Errera, supra note 58, at 411; Leary, supra note 33, at 387; Pechota, supra note 17 , at $487-88$.

64. With regard to private sanction processes, see, e.g., Paust, Response to Terrorism: A Prologue to Decision Concerning Private Measures of Sanction, 12 STAN. J. INT'L STUD. 79 (1977), and materials cited therein. 119.

65. See, e.g. , Leary, supra note 14, at 121; Leary, supra note 33 , at 383-90, 394; Oliver, supra note 15 , at

66. See, e.g., R. Lillich \& F. Newman, International Human Rights-Problems or Law and Policy 871 (1979); Fascell, supra note 21, at 354; Leary, supra note 33, at 384-86, 388-90, 393-95. On the monitoring of the United States, see also Leary, supra note 14, at 125-29; and Carliner, United Stales Compliance with the Helsinki Final Act: The Treatment of Aliens, 13 VAND. J. TRAnSNaT'L L. 397 (1980).

67. Leary, supra note 33 , at 375,377 . She attributes credit "for seizing upon" this provision to the groups in the USSR and Czechoslovakia. Id. at 394. For a similar viewpoint, see Errera, supra note 58 , at 427; Pechota, supra note 17, at 478-79, 484. Pechota adds that international support for such groups is "not only appropriate as an expression of human solidarity but also fully justified, both morally and juridically." See also supra text accompanying note 3; Fox, Remarks, 75 PrOC. AM. SOC. INT'L L. (1981) (in press).

68. See, e.g., supra note 8.

69. Universal Declaration, supra note 3 , at art 19. 


\section{B. Changes in Law}

Another effect of the Helsinki process has been to precipitate change in domestic laws and regulations of participating states. For example, in the United States a joint congressional-executive agency, the Commission on Security and Cooperation in Europe, was established to provide governmentally based monitoring of compliance with the Final Act. ${ }^{70}$ The President submits semiannual reports to the Commission ${ }^{71}$ which uses the reports as well as materials prepared by many private groups ${ }^{72}$ to issue its own publications and reports on the implementation of human rights. ${ }^{73}$ In the words of Professor Leary, "The Commission has served as a focal point for individuals and organizations . . . [and its] reports as well as its public hearings have been an indispensable source of useful information on implementation of the Accord."74

Certain changes in U.S. visa and immigration laws and regulations are a direct result of efforts to comply with the Helsinki Final Act. ${ }^{75}$ U.S. practice in that regard, however, has been severely criticized. ${ }^{76}$ A further example of U.S. developments is the Commission on Foreign Language and International Studies, which was established by President Carter to improve the "rather sad state" of foreign language instruction in this country in order to increase cultural understanding in accordance with the Final Act. ${ }^{77}$ Such an effort must logically contribute to the development of transnational human contacts and freedom of speech.

Other changes in law include incorporation of all ten principles of the Final Act's Declaration on Principles into article 29 of the 1976 Soviet Constitution. ${ }^{78}$ Human rights do not fare well, however, under other provisions of the Soviet Constitution as interpreted in practice by Soviet elites. ${ }^{79}$ Perhaps the new Treaty on Transboundary Air Pollution that arose out of the Helsinki experience will be more meaningful. ${ }^{80}$

70. 22 U.S.C. $\S 3001$ (1976). For background information on the creation of the Commission, see Leary, supra note 14, at 117-19.

71. See, e.g., Kiss \& Dominick, supra note 12, at 301.

72. See, e.g. , Oliver, supra note 15, at 118-19; Leary, supra note 33, at 386 (testimony before the Commission), 388-89, $391-93$ (numerous contacts and public hearings).

73. Sec, e.g., Fascell, supra note 21 , at 354 (first self-monitoring survey report); Leary, supra note 33 , at 378, 390-92; Oliver, supra note 15, at 119-20.

74. Leary, supra note 33 , at 392.

75. See, e.g. Cabranes, supra note 58, at 287; Carliner, supra note 66, at 400, $402 \mathrm{n} .25$; Leary, supra note 14 , at 128 ; Oliver, supra note 15 , at 120.

76. See, e.g. , Carliner, supra note 66; Leary, supra note 14, at 128. Carliner mentions the failure of the United States to eliminate barriers to travel and to promote family reunification. Sec Carliner, supra note 66 , at 399. He mentions especially passport and visa restrictions for short-term visitors to the United States and those seeking to emigrate, id. at 400 , and the selective exclusion of aliens from the United States by the executive branch, usually on "political grounds" or because of political beliefs of the applicant and/or membership in certain organizations. See id. at 407-08. Leary also mentions criticism of U.S. restrictions concerning short term entry visitors of a "suspect" ideological persuasion or membership. See Leary, supra note 14 , at 128 .

77. Oliver, supra note 15, at 120; see also Cabranes, supra note 58, at 287 (citing Exec. Order No. 12,054, 43 Fed. Reg. 17,457 (1978)).

78. See, e.g., Fascell, supra note 21 , at 346.

79. See, e.g., Uibopuu, The Human Righls Covenants, supra note 33; Dean, supra note 29; Feldbrugge, supra note 33, at 462 (arts. 39, 50-51, 62) passim; Paust, supra note 1, at 646-50.

80. See, e.g. Kiss \& Dominick, supra note 12, at 313; Fascell, supra note 21, at 352. 


\section{Domestic Cases}

Within the last six years, there has been little judicial use of the Helsinki Final Act. No known Eastern European cases use the Final Act, perhaps due to the fact that even the Universal Declaration of Human Rights has not been publicized and attempts to use it or any other human rights legal instruments in court proceedings have been repressed. ${ }^{81}$ In contrast, a judicial opinion in Turkey cited the Helsinki Final Act in striking down a law adversely affecting foreign journalists. ${ }^{82}$

In the United States, although only two federal courts have cited the Final Act in their opinions, the act has been cited by litigants and by the U.S. Government in an amicus brief during judicial proceedings. ${ }^{83}$ In a New York case addressing prison conditions, a petitioner argued that in the Final Act, as well as in other instruments, the United States had committed itself to fulfill its human rights obligations. ${ }^{84}$ The matter was finally settled by the state attorney general, "apparently because prison officials had violated prison rules." 85 A more important development involved the U.S. Government's amicus brief before the Second Circuit in Filartiga v. Pena-Irala ${ }^{86}$ There, the Government recognized that customary international law includes the obligation of nation-states "to observe fundamental human rights." 87 The Government's brief also recognized that the Universal Declaration of Human Rights "goes beyond the UN Charter in specifying and defining the fundamental rights to which all individuals are entitled," adding: "The Universal Declaration has been followed by a growing number of UN resolutions clarifying and elaborating on these rights or invoking them in specific cases." 88

The Government then took this position on the legal nature and effect of the Helsinki Final Act: "In a parallel development, the International Conference on Security and Cooperation in Europe . . . adopted a Final Act . . . . The Final Act, like the UN resolutions, does not have the legal effect of a treaty but provides evidence of customary international law."89 The Court in Filartiga utilized the Universal Declaration to identify the content of Charter obligations and cus-

81. See generally Pechota, supra note 17 , at $482-83,494$.

82. See Aybay, The Intemational Human Rights Instruments and the Turkish Law, TURKISH YRBK. OF H.R. 17, 23-25 (1979); Nimetz, supra note 15 , at 36 .

83. Haig v. Agee, 453 U.S. 280, 300 n.48 (1981) (purpose of amendment of the Passport Act was to achieve greater compliance with the Helsinki Final Act); Jones v. Unknown Agents of Fed. Elec. Comm'n, 613 F.2d 864, 869 n. 10 (D.C. Cir. 1979).

84. See Turner v. Ward, Superior Court (1977), reprinied in R. LILliCH \& F. NewmaN, supra note 66, at $120-21$.

85. R. Lillich \& F. NEwMAN, supra note 66 , at 121.

86. 630 F.2d 876 (2d Cir. 1980). Filartiga involved a private cause of action under 28 U.S.C. $\$ 1350$ (1976) (the Alien Tort Statute) for torture and wrongful death of a Paraguayan youth by a Paraguayan Inspector General of Police. Human rights and other norms of international law were relevant with regard to questions concerning both federal court jurisdiction and the substantive law upon which a cause of action under 28 U.S.C. $\S 1350$ rests. For further exposition, see, e.g., Paust, Human Rights, supra note 3, at 230:32, 234-37, 240-44, and Symposium, 4 Hous. J. INT'L L. 1 (1981).

87. Amicus Brief for the United States at 9, Filartiga v. Pena-Irala, 630 F.2d 876 (2d Cir. 1980) [hereinafter cited as Amicus Brief]. The Amicus Brief has been reprinted at 19 INT'L L. MATERIALS 585 (1980). See also Amicus Brief supra at 5, 8, 10-11.

88. Amicus Brief, supra note 87 , at 9 .

89. Id. at $9-10$ 
tomary international law. ${ }^{90}$ Unfortunately, the court made no mention of the Helsinki Final Act. In any event, the recent Filartiga and Fernandez v. Wilkinson ${ }^{91}$ cases should prove to be of significance during efforts to provide greater judicial recognition and implementation of fundamental human rights. ${ }^{92}$

\section{Other Practices}

One of the most noted effects of the Helsinki process has been the increased freedom of movement across state boundaries for individuals and the interrelated impact of this freedom upon family reunification. ${ }^{93}$ Although free emigration has been spotty and relatively rare, ${ }^{94}$ the Helsinki process has contributed to the greater enjoyment of such a human right, particularly in light of historic conditions. ${ }^{95}$ As several have commented, the Helsinki process has allowed the United States more direct bilateral contact with Eastern European governments, ${ }^{96}$ which has resulted in freer emigration, more family reunification, and, within certain countries, a greater freedom in the exercise of religion. ${ }^{97}$

These practices have contributed somewhat to a freer flow of ideas, but most agree that the records of Soviet and other Eastern European countries on transnational freedom of speech continue to be very poor, ${ }^{98}$ with the possible exception of Yugoslavia. ${ }^{99}$ As Ambassador Goldberg has written of the Belgrade follow-up meeting in 1977-78, "We expressed our deep concern about repression . . . , about the jamming of radio broadcasts, [and] about the failure to permit adequate dis-

90. See Filartiga v. Pena-Irala, 630 F.2d at 879; Paust, Human Rights, supra note 3, at 230, 234-36, 240, 244.

91. 505 F. Supp. 787 (D. Kan. 1980). Femandez involved habeas corpus challenges to the detention by the United States of several hundred Cuban refugees in a maximum security prison for more than six months without charges. Human rights and other norms of international law were used by the district court as a basis for its conclusion that federal detention was unconstitutional, and by the circuit court as aids for the interpretation of relevant statutory and constitutional norms. For further exposition, see, e.g., Paust, Human Rights, supra note 3, at 232-36, 242, 244, and Symposium, 4 Hous. J. INT'L L. 1 (1981).

92. See Paust, Human Rights, supra note 3, at 229, 244 passim.

93. See, e.g., Leary, supra note 14, at 132-33; Dean, supra note 29, at 86; Thomas, 73 Proc. AM. Soc. INT'L L. 136 (1979); Thomas, 70 PROC. AM. SOC. INT'L L. 65, 72 (1976); Turack, supra note 3, at 109 passim; Turack, supra note 14, at 590 passim; Assistant Secretary of State Vest, supra note 15, at 53; Nimetz, id. at 92,95 .

94. See Nimetz, supra note 15 , at 92.

95. For more detailed consideration of this human right, see, e.g., M. McDougal, H. LAsswELL \& L. CHEN, supra note 3, at 895 passim; Universal Declaration, supra note 3, arts. 3, 4, 9, 13(2), 15(2); Uibopuu, The Human Rights Covenants, supra note 33, at 45-49; Uibopuu, In Search of a Most Favorable Status for Refugees: A Comparison of Intemational Legal Instruments Dealing with Human Rights, 14(23) A. WORLD REFUGEES BULL. 149, $154-57$ (1976).

96. See, e.g. , Vest, supra note 15, at 53; Nimetz, supra note 15, at 94-95; Fascell, supra note 21, at 353 (also mentioning an extensive human rights meeting between the United States and Romania in 1980). On the utility of the Helsinki process for human rights "discussion and persuasion," see Hansell, 71 Proc. AM. Soc. INT'L L. 207, 209 (1977); see also Friendly, 73 Proc. AM. SOC. INT'L L. 195 (1979); Comment, supra note 14 , at 138 .

97. Countries mentioned were: Bulgaria, Hungary, Poland, Romania, and Yugoslavia (which is one of the most open and is labeled as nonaligned).

98. See, e.g., Feldbrugge, supra note 33, at 456, 462, 464; Leary, supra note 14, at 140-48; Nimetz, supra note 15, at 92-93; Paust, supra note 2, at 646-52; supra notes 33, 34, 61 .

99. Compare Dimitrijević, supra note 2, at 263 with Paust, supra note 2, at 651 , and materials cited therein and Turner, supra note 61 , at 318 . 
semination of Western newspapers, books, and religious materials . . . "100 Such practices continue even though the United States and the Soviets spend billions annually on radio and other media for global propaganda efforts. ${ }^{101}$ Certainly there are other policies at stake-policies relating to human dignity, individual freedom, free speech, equitable development and sharing of information, wealth, power, self-determination, public order, national security, and "cultural imperialism"102_but continued oppression is the clear result.

\section{IV \\ Present Legal Utility of the Act}

\section{A. Freedom to "Know and Act"}

As mentioned, the Helsinki Final Act, by merely reaffirming the right of individuals to "know and act," has important legal utility in connection with efforts to assure widespread enjoyment of human rights. Most Western writers have recognized another important reaffirmation contained in principle VII-the recognition of "the universal significance of human rights and fundamental freedoms, respect for which is an essential factor for . . . peace, justice and well-being . . . ." As writers tend uniformly to proclaim, such a recognition constitutes a significant admission by each participating state that respect for human rights is an international concern and is not within the exclusive province of any particular state within the meaning of article 2, paragraph 7 of the UN Charter. ${ }^{103}$ In this sense, states and other entities also have a right to "know and act."

This is an important reaffirmation, and its utility does not depend upon whether the principles of the Final Act are legally binding. Indeed, the entire Helsinki process has helped to further internationalize human concern about state violations of human rights. It does not matter that the obligations themselves are

100. Goldberg, supra note 33, at 319.

101. See The Propaganda Sweepstakes, Time, Mar. 9, 1981, at 15.

102. Compare the policies mentioned in Robinson, Regulating Intemational Ainuaves: The 1979 WARC, 21 VA. J. INT'L L. 1, 3-5, 13, 15, 18-20, 40 n. 120 (1980) with Paust, supra note 2, at 624-30, 648-50 and Cassese, supra note 3 , at 284 (recognizing the relation between free speech and self-determination, and thus principles VII and VIII of the Final Act). Robinson speaks of a "new world information order," Robinson, supra at 19, 40 n.120, but such may either be continually thwarted by state oppression or will, eventually, override even the most ardent of the oppressive state elites. Indeed, Professor Michael Reisman has recently warned that the phrase "new world information order" has developed partly into a euphemism for state elite attempts to control the free flow of information. See Reisman, supra note 35; see generally 73 PROC. AM. SOC. INT'L L. 183 (1979).

103. See, e.g., L. Henkin, R. Pugh, O. Schachter \& H. SmitT, supra note 14, at 213; J. StaRke, InTRODUCTION TO INTERNATIONAL LAW 400 (8th ed. 1977); Buergenthal, supra note 13, at 7; Cabranes, supra note 58, at 286; Carliner, supra note 66, at 398; Cassese, supra note 3, at 288-89; Chalidze, supra note 17, at 433; Coughlin, supra note 14, at 512-13; Dimitrijević, supra note 3, at 254, 262, 265-67, 270; Fascell, supra note 21, at 343; Fox, supra note 67; Goldberg, supra note 33, at 318; Goldberg, supra note 14, at 250; Goldberg \& Fay, Human Rights in the Wake of the Helsinki Accords, 3 Hastings INT'L \& COMP. L. REV. 1, 6 (1979); Goldberg, Human Rights-An Issue For Our Time, 29 Hastings L.J. 887 (1978); Henkin, supra note 14 , at 23; Higgins, supra note 16, at 1, 4-5, 11; Jonathan \& Jacqué, supra note 12, at 51; Kiss \& Dominick, supra note 12, at 301-03; Leary, supra note 14, at 113; Nafziger, supre note 3, at 570; Nimetz, ABA Workshop, supra note 15, at 90; Oliver, supra note 15, at 34-35; 86; Pechota, supra note 17, at 472-74; Robertson, supra note 16, at 40-43; Russell, The Helsinki Declaration, supra note 15, at 263; 268; Schneider, 72 PROC. AM. SOC. INT'L L. 203 (1978); Turack, supra note 3, at 114; Turack, supra note 14, at 605-06; ILA REPORT, supra note 16, at 131, 133; Comment, supra note 14, at 137, 147. 
primarily moral or political; what matters is that there has been an internationalization of such human concern. ${ }^{104}$ This clearly has occurred.

\section{B. Use as an Interpretive Aid}

The fact that the Helsinki Act, whether or not it is a legal document, has contributed to international law by reaffirming human rights and correlative nationstate obligations is generally recognized. ${ }^{105}$ Thus, the Final Act can play an important role by furthering and perhaps reshaping patterns of legal expectation concerning human rights. It has also been suggested that the Helsinki Act can play a useful role as an interpretive aid or as evidence of further refined content concerning such human rights matters as transnational speech. ${ }^{106}$

As explained by Professor Tom Buergenthal, "various provisions of the Helsinki Final Act may be viewed as evidence of the practice of states . . . [and] can assist in establishing authoritative interpretations of ambiguous international instruments . . . ."107 Later, he added:

The human rights provisions contained in Basket III . . . are for the most part narrower in scope and more specific . . . [and] whenever the Basket III provisions are more specific than those set out in various obligatory international human rights instruments . . ., the former may be resorted to by the signatory states to clarify the meaning of the latter, including the intended reach of available defenses, limitations, and escape clauses . . . 108

The problem with this nearly unqualified acceptance of the Final Act as an interpretive aid is that despite the suggestions of such a utility by certain textwriters, a more broadly based expectation that the Act is, in toto, an authoritative documentation of human rights content is still lacking. Some provisions undoubtedly mirror human rights law; some are arguably relevant as authoritative interpretive aids. Are other provisions merely representative of a new "political" or "moral" will? Do some provisions lack a basis of support in patterns of generally shared legal expectation? ${ }^{109}$

There would have to be a better demonstration of actual patterns of acceptance of the Basket III provisions as legally relevant interpretive aids before one could conclude that the Act is useful as an authoritative guide to content. We may be close to such an acceptance, especially as private groups increasingly rely on the

104. See, e.g., R. Lillich \& L. Newman, supra note 66, at 5, 37, 67, 864-66; M. MCDOuGAL, H. LASSWELl \& L. CHEN, supra note 3, at 208-15 passim. For a related point, see also Amicus Brief, supra note 87 , at $3,10-12$.

105. On this general point, see, e.g., Buergenthal, supra note 13, at 6, 8; Cassese, supra note 16, at 105; Cassese, supra note 3, at 275; Errera, supra note 58, at 412,426-27; Frowein, supra note 12, at 72; Jonathan \& Jacqué, supra note 12, at 45-46, 52; Kiss \& Dominick, supra note 12, at 304, 306; ILA REPORT, supra note 16, at 128, 130; Nimetz, supra note 15, at 59; Comment, supra note 14, at 137-39, 145; see also Higgins, supra note 16 , at 4,11 .

106. See, e.g., R. LILlich \& L. NeWMAN, supra note 66, at 849 (Kissinger stating that basic principles of human rights are "in" the Final Act); Buergenthal, supra note 13, at 6-9; Cassese, supra note 16, at 10507; Frowein, supra note 12, at 72-77; Jonathan \& Jacqué, supra note 12, at 46, 52-53 (sometimes "more specific" or "adds interesting clarifications"); Russell, The Helsinki Declaration, supra note 15, at 248 ("viewed . . . as consistent with international law"); Uibopuu, supra note 16, at 224-25; see also Nanda, Book Review, 13 Vand. J. Transnat'L L. 503, 504 (1980).

107. See Buergenthal, supra note 13 , at 6-7, summarizing conclusions of a conference.

108. Id. at 8-9.

109. See also supra notes 35-39. 
Helsinki provisions in making legal claims. ${ }^{10}$ Nevertheless, we do not seem to have reached such a stage at this time. It may be argued that the United States' amicus brief in Filartiga refutes the last point, but such language may be read restrictively at present (i.e., "provides evidence" might be read "in part provides evidence" of customary law), 11 especially since some of the Basket III provisions proved relatively contentious during the conference proceedings. ${ }^{112}$

Similarly, claims have been made that the Helsinki Final Act estops participating states from denying the legal nature of its provisions. ${ }^{113}$ But such a claim ultimately begs the same sort of question. It is an ingenious argument. In this case, however, permissible reliance in connection with estoppel theory relates best to a reliance upon foreign state declarations that evidence that state's acceptance or recognition of some standard as a legal standard. ${ }^{114}$ These claims seek to estop a foreign state's denial that it is legally bound by certain declarations previously made concerning legally relevant standards or, more generally, its legal obligations.

The estoppel claims are not concerned primarily with moral or political obligations as such, although the concept of a "political obligation" raises interesting questions. Presumably, the Helsinki signators are estopped from denying the moral and political nature of the obligations assumed in the Final Act. Although they may not be illusory, ${ }^{115}$ these obligations rest on a different set of expectations - those regarding the appropriateness of a partial or total noncompliance or the consequences of noncompliance, for example. ${ }^{116}$

For these reasons, it seems more advantageous to stress the legal authoritativeness of the UN Charter human rights obligations and the legally relevant, if not customary, content of the Universal Declaration of Human Rights. These instruments reflect the human right to transnational freedom of speech. With this in mind, one can view the Basket III provisions of the Final Act partly as reflecting

110. See, e.g., Pechota, supra note 17 , at 479 passim; supra notes 58 and 60 .

111. See supra text accompanying note 89.

112. See, e.g., Jonathan \& Jacqué, supra note 12, at 47 ("freedom of information-the most sensitive subject"), 61 ("differences. . . most pronounced" and still differences in "interpretation and implementation"). Cf. id. at 65.

113. See, e.g. , Cassese, supra note 16, at 106-07; Uibopuu, supra note 16, at 225; see also Schachter, supro note 13, at 301. Both Professors Uibopuu and Cassese seemed to address estoppel only in connection with the process of self-determination and prior Soviet theories that are thwarting the full meaning of such a process and its relation to other human rights.

114. See, e.g., North Sea Continental Shelf Cases, 1969 I.C.J. Rep. 3, 25-26 (on the need for assumption, acceptance or recognition of a standard as a legal standard); see also id. at 41-45 (on the need for opinio juris); Nuclear Test Cases (Australia v. France), 1974 I.C.J. Rep. 253, 267-68 and (New Zealand v. France), id. at 457, 472-73; Rubin, The Intemational Legal Effects of Unilateral Declarations, 71 AM. J. INT'L L. 1 (1977).

115. See, e.g., supra text accompanying note 22. It should also be noted that some "laws" may, through time, prove to be more "illusory" than political agreements when the pattern of supportive expectations changes. The same point can be made concerning what a lawyer believes to be a legally binding contract but what a businessperson more realistically considers to be a workable process of agreement that rests upon mutual but changeable expectations. Similarly, what a technical legal interpreter might classify as mere "illusory" promises could form the basis of a functional process of agreement that outlasts the most legally sanctified of contract relationships.

116. Consider, for example, the patterns of expectation involved in a "nonbinding" business relationship. 
legal content and partly as a demonstrated political will "to proceed to the implementation of' 117 legal and political goals and obligations. Indeed, many of the provisions are couched in implementary language, ${ }^{118}$ thus demonstrating what appears primarily to be a political will to implement.

In this sense, the statement contained in Basket III that the participating states make it "their aim to facilitate the freer and wider dissemination of information of all kinds," 19 or that they intend "in particular . . . [ $\mathrm{t}]$ o contribute to the improvement of access by the public to periodical and non-periodical printed publications,"120 takes nothing away from the human rights obligations of the UN Charter, as authoritatively supplemented by the Universal Declaration. ${ }^{121}$ Such statements take nothing away from the legal expectation documented in article 19 of the Universal Declaration of Human Rights that everyone has the right "to seek, receive and impart information and ideas through any media and regardless of frontiers."122 What is sometimes neglected is an adequate implementation of such a right. The general legal expectation continues that such a right should have a remedy. ${ }^{123}$ Helsinki, in this sense, seeks a more adequate remedy.

Additionally, the authoritativeness of human rights law does not rest on the consent or lack of consent of any particular state. What is needed in the international community is a generally shared expectation, rather than total consent. ${ }^{124}$ Thus, it would not matter that the Soviet Union, as a law violator, did not consent to an international legal norm. Nor would it matter that the Soviet Union misinterpreted the "necessity within democratic limits" test of permissible restrictions of free speech ${ }^{125}$ and engaged in conduct that was violative of international law. As suggested by Professor Jochen Frowein, the "escape clauses" are not interpreted in a final way by a particular state. ${ }^{126}$ Rather, they are only provisionally interpreted with the possibility of community review. ${ }^{127}$

117. Basket III, $\S 1$ (Human Contacts), preamble.

118. For example, much of the relevant language of $\S 2$ (Information) reads: "aim to facilitate," "will encourage," "will facilitate," "will take appropriate measures," "will favour." Id. $\S 2$.

119. Id. $\S 2$, preamble.

120. Id. $\S 2(\mathrm{a})(\mathrm{ii})$. For evidence of different East European practices in this regard, see, e.g., Jonathan \& Jacqué, supra note 12 , at 62 .

121. See Paust, supra note 2, at 631 ; see also supra text accompanying note 12 (quoting principle $\mathrm{X}$ of the Final Act).

122. See supra note 2 .

123. See supra note 8.

124. See, e.g., Paust, Comment, supra note 39, and cases cited; North Sea Continental Shelf Cases, supra note 114, at 41-45.

125. For a detailed consideration of this test, see Paust, supra note 2, at 626-29, 664. Here, it should also be noted that the overall nature of a state's "political, economic or social system" as such is not a relevant factor. See also Final Act, supra note 1, preamble; Higgins, supra note 16, at 2.

126. Frowein, supra note 12, at 76-77.

127. See also M. McDougal \& F. Feliciano, Law and Minimum World Public. Order 218-20 (1961). For recent evidence of the Hurnan Rights Committee's view of a nation-state's "burden of proof" with regard to alleged violations of the International Covenants, see Commentaries: Human Rights Commiltee, REV. INT'L COMM'N JURISTS, Dec. 1980, at 35, 37-38. 


\section{V \\ Future Potential}

Perhaps the most realistic future legal potential of the Helsinki Final Act involves its more broadly based acceptance as an interpretive aid. If its authoritativeness as a guide increases, the Final Act might be utilized to provide an expanded meaning of transnational freedom of speech. Perhaps then, as suggested by Professor Frowein, it will evidence a more expanded or detailed content that cannot be excluded from the meaning of other human rights instruments. ${ }^{128}$

Here it is assumed that the Final Act will continue to have important legal effects whether or not it obtains a legal status. The role of the Helsinki process in stimulating private attitudes and behavior will be particularly important. Someday there may exist widespread expectations that the entire Final Act exemplifies either customary nation-state obligations or human rights content, or both. But such a customary status is for the future. ${ }^{129}$

In the meantime, there exists a human right to transnational freedom of speech-a right partly thwarted by certain state elites, but partly furthered by the Helsinki process and a revolution in communications technology that may serve even more effectively than "binding" legal documents to liberate human thought and communication from oppression by state elites. Against those who choose in the future to deny such a human right, the "rocks and stones themselves" may also "start to sing." 130

128. See Frowein, supra note 12, at 76-77.

129. See also Buergenthal, supra note 13, at 6-7; Kiss \& Dominick, supra note 12, at 315; Russell, The Helsinki Declaration, supra note 15, at 248.

130. Hosanna, in Jesus Christ Superstar (A. Webber \& T. Rice 1970). The full paragraph reads, "Why waste your breath moaning at the crowd? Nothing can be done to stop the shouting. If every tongue was still the noise would still continue. The rocks and stones themselves would start to sing . . . ." Today the "rocks and stones" can "sing"-when fashioned by human hands into telecommunication satellites and other media instruments. 